FACTA UNIVERSITATIS

Series: Philosophy, Sociology, Psychology and History Vol. 20, No 1, 2021, pp. 25 - 37

https://doi.org/10.22190/FUPSPH2101025V

Original Scientific Paper

\title{
THE RELATIONSHIP BETWEEN AFFECTIVE TEMPERAMENT AND PERCEIVED SOCIAL SUPPORT
}

\author{
UDC 159.923.4.072
}

\author{
Dušan Vlajić1 , Danica Trajković \\ ${ }^{1}$ University of Niš, Faculty of Philosophy, Department of Psychology, Niš, Serbia \\ ${ }^{2} \mathrm{Niš}$, Serbia
}

\begin{abstract}
This paper examines whether people with different affective temperament (depressive, cyclothymic, hyperthymic, irritable, anxiety-cognitive, anxiety-somatic and mixed) differ in terms of perceived social support. The sample is a convenience one, uniform by gender, consisting of 200 people under the age of 35. The instruments used in the research are: the Serbian version of the TEMPS-A scale, which assesses five affective temperaments, and the Serbian version of the Social Support Scale of the Study of Medical Outcomes (MOS-SSS). The results show that the depressive temperament perceives social support to a lesser extent than the cyclothymic $(p<.05)$, hyperthymic $(p<.01)$, anxietycognitive ( $p<.05)$ and mixed temperament ( $p<.05)$. On the other hand, the hyperthymic temperament is more prone to perceiving social support than the cyclothymic ( $p<.05)$ and anxiety-somatic temperaments are ( $p<.05)$. The main conclusion of this research is that hyperthymic temperament, which is characterized by most desirable traits such as optimism, sociability, self-confidence and eloquence, perceives its social environment to be more supportive than other temperaments, which is a consequence of its characteristics and the adequate communication of its own needs.
\end{abstract}

Key words: affective temperament, perceived social support, social support dimensions.

\section{INTRODUCTION}

\subsection{Affective temperaments}

The definition of temperament usually encompasses genetic-biological components of behavior, which are manifested through a series of signs and characteristics that include a certain stable mood, attitude towards the environment, sensitivity to external stimuli and

Received June 4, 2020 / Accepted July 27, 2020

Corresponding author: Dušan Vlajić

University of Niš, Faculty of Philosophy, Ćirila i Metodija 2, 18000 Niš, Serbia

E-mail: dusan.vlajic@ filfak.ni.ac.rs 
a characteristic way of reacting (Ratković 2017). The elements of temperament are usually: motor activity, rhythmicity, adaptability, the irritability threshold, reaction intensity, mood quality and ability to direct and maintain attention (Goldsmith et al. 1987; according to Ratković 2017).

One's personality can be defined as a kind of "mixture" of temperament types. More precisely a person's experiences, feelings and emotional reactions, can be related to temperament. This explanation originates from Hippocrates and Aristotle (DembińskaKrajewska \& Rybakowski 2014). The following conception, relevant to the modern understanding of temperament, originates from Greece and Roman medicine, which assume that temperament is a constitutional pattern of emotional reactivity (Akisakl \& Akiskal 2007; according to Dembińska-Krajewska \& Rybakowski 2014). Krepelin's teaching continued this tradition and formed the theory of four types of temperament (depressive, manic, cyclothymic and irritable), which were conceptualized as subclinical forms of affective disorders (Dembińska-Krajewska \& Rybakowski 2014). Hagop Akiskal accepted and further developed the aforementioned concept of temperament (2007; according to Dembińska-Krajewska \& Rybakowski 2014). This author states that there are five affective temperaments - depressive, hyperthymic, cyclothymic, irritable and anxious.

Depressive temperament represents people who are shy, prone to being submissive, prone to routine and self-blame, sensitive to criticism, but also prone to self-denial, sensitive to the suffering of others, reliable and persistent (Akiskal \& Akiskal 2007; Dembińska-Krajewska \& Rybakowski 2014). In general, they are characterized by a lack of energy, which prevents them from participating in tasks that require a high level of activity (Ibid).

Hyperthymic temperament consists of the largest number of "positive" traits: they are optimistic, fun, sociable, prone to jokes, self-confident, full of ideas, eloquent, constantly on the move. They do not need a lot of sleep, they are full of energy, do not get easily tired, show the highest intensity of emotional reactions and have a propensity to leadership (Ibid). The bad traits of this type are that they look at the problem one-sidedly, are prone to taking risks and they do not accept criticism at the expense of their character and intrusiveness (Akiskal \& Akiskal 2007; Dembińska-Krajewska \& Rybakowski 2014).

The cyclothymic temperament is of variable mood, energy and self-confidence, and unstable in social relations. A positive feature of this temperament is the high level of creativity. However, these people are prone to superficial thinking, but also ready to make an intellectual effort to understand the situation. Intense feelings are a part of their experience, they have a tendency toward emotional outbursts and are ready to quickly enter into new relationships (Dembińska-Krajewska \& Rybakowski 2014).

The irritable temperament has some desirable intellectual traits, like skepticism and criticism. On the other hand, it has the "darkest" nature of all, as these individuals often complain and are grumpy, dissatisfied, prone to anger, violence, and sexual jealousy (Akiskal \& Akiskal 2007). The irritable temperament partially coincides with the cyclothymic, but differs from it by having a higher energy level and a lower level of empathy (Dembińska-Krajewska \& Rybakowski 2014).

People with an anxious temperament are prone to worry and rumination, and experience constant physical and mental tension that can lead to somatic symptoms (Ibid). From the previous description, it can be concluded that all the temperaments have both positive and negative characteristics, and thus can either favorably or adversely affect quality of life and social interactions. 
Research has shown that affective temperaments are stable over time (Kawamura et al., 2010, according to Oniszczenko \& Ledzińska 2019) and that they have both universal and culturally specific characteristics (Vázquez, Tondo, Mazzarini \& Gonda 2012, according to Oniszczenko \& Ledzińska 2019). Temperaments underlie stable behavioral patterns and personality traits (Rovai et al. 2013b, according to Oniszczenko \& Ledzińska 2019), but they can also play a key role in the predisposition for the development of affective disorders and addiction, especially when they are too intense (Ratković 2017).

The cyclothymic temperament shows great difficulties in interpersonal relationships (Rovai et al. 2013a). The depressive temperament is associated with a decreased ability to interact with others and problems in interpersonal relationships (Ibid), but also with a tendency to worry, and problems with concentration (Walsch et al. 2013). The depressive and cyclothymic temperaments have a manifested increased reactivity to stress (Ibid). On the other hand, the hyperthymic temperament was positively associated with the experience of pleasant emotions, high energy, carefreeness, sociability, a positive perception of everyday life, but also a grandiose perception of self (Ibid), as well as a high level of emotionality (Rovai et al. 2013a).

\subsection{Perceived social support}

Generally speaking, social support is defined as an act or process that provides help or support (Zvizdić 2000; according to Zvizdić 2015). One possible definition is that social support is support available to a person through connections with other individuals, groups, and the larger community (Lin et al. 1979; according to Zvizdić 2015). The previous definition emphasizes the importance that interpersonal relationships have on providing social support. One more comprehensive definition is that social support is emotional, informational, or practical help from significant others, such as family members, friends or colleagues, and that it can be received by others or perceived as available when needed (Thoits 2010; according to Nurullah 2012).

Two basic aspects of social support are structural and functional (Cohen \& Wills 1985; according to Zvizdić 2015). Structural support refers to the network of social relations of a person, i.e. the number of people providing support and roles that those people have (e.g. spouse, friend, colleague, etc.). Sarason, Levine, Basham and Sarason (1983; according to Zvizdic 2000) define the structural type of support as the real existence of people that an individual can rely on, i.e. people who value, care and love him/her. On the other hand, functional social support consists of perceived support, which is the belief of an individual that he has a common network of significant and interested supportive others (Zvizdić 2015) and receives support from a person.

One of the models of perceived social support was developed as part of a longitudinal study of medical outcomes, which aimed to examine the quality of life of people suffering from chronic diseases such as hypertension and diabetes (Tarlov et al. 1989; according to Jovanović \& Gavrilov Jerković 2015). The MOS-SSS was developed within the mentioned study, and distinguishes five dimensions of perceived social support:

1. emotional, or the availability of a person who understands us and our problems and who is willing to listen to us and with whom we can share concerns;

2. informational - the availability of a person to whom we can turn for advice or information; 
3. tangible - the availability of a person who can help us when we are sick;

4. affectionate - the availability of a person who loves us and who shows us love and attention;

5. positive social interactions - the availability of a person with whom we can have a pleasant time and with whom we can relax and enjoy ourselves.

Previous definitions and explanations clearly show that social support is one of the most important types of social interactions. In any situation where there is the possibility that we will be negatively assessed by others, stress levels will rise (Dickerson \& Kemeny 2004). Lazarus (1966; according to Frisch et al. 2014) states that the experience of stress, including behavioral and bodily reactions, takes place through a two-step appraisal process: the first, called primary appraisal, involves assessing the harmfulness of a stressful situation, and the second (secondary appraisal), the assessment of one's own potential to overcome a stressful situation. Frisch et al. (2014) state that social support can have a positive effect on both assessment steps, more precisely on the prevention of the stressor reaction and on the mitigation of the stress response effects on the body.

However, although perceived social support has been shown to be more significant than received social support in adjusting to stressors, social support may not always have a positive effect (Nurullah 2012). Sometimes, social support not only insufficiently reduces stressful reactions, but can intensify them and make them more undesirable for the individual, especially if the support is perceived as imposed (Deelstra et al. 2003; according to Nurullah 2012). Some explanations of these findings can be found in the literature. One of them states that the connection between received social support and stress is often blurred by the fact that people who experience the most stress usually receive the most support and have the worst mental health (Lakey \& Orehek 2011). Other explanations state that receiving social support can create a feeling that a person is indebted to the provider, it can lead to impaired self-confidence or guilt in the recipient, or support may be inadequately given (Nurullah 2012).

There are studies showing that the personality of the recipient is crucial for the manner of perception and the effect of social support. A longitudinal study of women living in Islington showed that social support at a time of significant loss or disappointment reduces the chances of developing clinical depression (Brown et al., 1986; according to Andrews \& Brown 1988). However, a longitudinal study in Canberra failed to find a similar link, and it was concluded that such findings led to the interpretation of adequate support as "inadequate" by those who develop depressive symptoms over time (Henderson et al. 1981; according to Andrews \& Brown 1988). So, the quality of the support itself is not important. What matters are personality traits or a person's needs (Andrews \& Brown 1988).

The importance of factors originating from the recipient, which directly determine the quality of social support provided, is further indicated by observations that some people are not assertive enough when seeking help, that some do not want to be a burden to others, do not feel comfortable while dependent on others or they simply do not know who to turn to (Sarafino 1998; according to Zvizdić 2015). Bolger, Zuckerman \& Kessler (2000; according to Frisch et al. 2014) state that emotional support can be perceived as a danger to an individual's self-confidence and can lead to feelings of inefficiency. Therefore, the authors further argue that social support will have more benefits for the individual if it is interpreted without distrust and with a general positive attitude towards others who provide support. 
Temperament, as the biological basis on which a personality is built, makes individuals to varying degrees sensitive to stressors from the environment. More precisely, temperament influences the experience of stress and its consequences, by determining the way people perceive and react to stressors and the way they cope with a stressful situation (Strelau \& Zawadzki 2011; according to Rzeszutek, Partyka, \& Gołąb 2015). Adverse temperament characteristics can predispose an individual to have negative social interactions with significant others (Thomas \& Chess 1977; according to Katainen et al., 1999), which can further result in depressive reactions. Windle (1992; according to Katainen et al. 1999) reported that part of the influence of temperament on the propensity for depressive reactions can be attributed to a reduced level of perceived support from friends and family. There is also an opinion in the literature (Finch \& Graziano 2001) that temperament influences the expression of the structure and personality traits, which predispose a person to a certain type of social exchange, both positive and negative. These exchanges, consequently, affect the mental health of the individual and the eventual development of certain distress symptoms.

Based on all of the above, we can conclude that the literature emphasizes the importance of permanent dispositions of personality in determining how to respond to stress, as well as the perception of available social support. Among these permanent dispositions, temperament characteristics including Askikal's affective temperaments play a significant role. With all that being said, and being in line with the authors' knowledge of this topic, the relationship of these concepts was not examined on a Serbian sample. The main goal of this research is to examine whether people of different affective temperament differ in terms of the degree of perception of available social support. It is assumed that there is a statistically significant relationship between temperaments and the propensity to perceive social support, more precisely that the hyperthymic temperament will largely perceive available social support, given that these individuals are optimistic, social, like to take the lead (Dembińska-Krajewska \& Rybakowski 2014), as well as show a tendency towards a positive perception of everyday life (Walsch et al. 2013). Also, people with depressive temperament are expected to be less likely to perceive available social support, given that they have difficulties in interpersonal relationships (Rovai et al. 2013a) and are inhibited compared to others (Signoretta et al. 2005).

\section{METHOD}

\subsection{Instruments of the research}

For assessing temperaments, the Serbian version of the temperament scale Temperament Evaluation of Memphis, Pisa, Paris and San Diego-autoquestionnaire - TEMPS-A (RistićIgnjatović et al. 2014) was used. The questionnaire contains 41 questions that respondents answer by circling $\mathrm{T}$ (true) or $\mathrm{N}$ (false) depending on whether or not they agree with the statement. The items are grouped into 6 categories, depending on the temperament they are referring to: depressive, cyclothymic, hyperthymic, irritable, anxiety-cognitive or anxietysomatic. The authors of the Serbian validation study (Ristić-Ignjatović et al. 2014) separated the unique anxiety factor into: anxiety-cognitive, referring to a tendency to worry and largely coincides with depression, and anxiety-somatic, referring to somatic correlates of anxiety and including stress-induced symptoms such as: headache, trembling hands, abdominal discomfort, nausea, diarrhea, frequent visits to the toilet, etc. In this study, the reliability coefficient (Cronbach's $\alpha$ ) for these scales is: depressive $\alpha=.75$, cyclothymic $\alpha=.82$, hyperthymic $\alpha=.69$, irritable $\alpha=.69$, anxiety-cognitive $\alpha=.78$ and anxiety-somatic $\alpha=$ 
.66 , which is in line with the results obtained in the domestic validation study (RistićIgnjatović et al., 2014). The instrument also contains an additional question about the global subjective impression, in which the respondents are asked to complete one of the 6 offered statements which, in their opinion, best describes their temperament traits.

The scale of social support of the Study of Medical Outcomes - MOS-SSS (Jovanovic \& Gavrilov Jerković 2015) is an instrument which consists of 19 items, referring to five dimensions of social support: emotional, informational, tangible, affectionate and positive social interactions. Respondents express the degree of agreement with the content on a fivepoint Likert-type scale $(1=$ never, $2=$ rarely, $3=$ sometimes, $4=$ often, $5=$ always $)$. The authors of the domestic validation study (Jovanović \& Gavrilov Jerković 2015) state that the results of the initial verification of the scale structure, conducted by Sherbourne \& Stewart (1991), showed that the Emotional and Informational Support subscales have a very high correlation, and that items are grouped within a subscale called Emotional / Information Social Support. The mentioned validation study on the Serbian sample showed that the structure of the scale is best described by a bifactor model, which assumes the existence of one general factor of social support and four specific factors: Emotional / Informational support (8 items), Tangible support (4 items), Affectionate support (3 items) and Positive social interactions ( 3 items), but it is only possible to reliably interpret the total MOS-SSS score. The questionnaire also contains an additional item under the ordinal number 13. The value of Cronbach's coefficient for the entire scale in this study is $\alpha=.96$, and the reliability coefficients of individual subscales have the following values: Emotional / Informational support $\alpha=.94$, Tangible support $\alpha=.87$, Affectionate support $\alpha=.87$ and Positive social interactions $\alpha=.87$.

\subsection{Sample}

The sample is a convenience sample and consists of 200 people (100 men and women) under the age 35, of different levels of education. The age of the respondents ranges from 17 to 35 years $(\mathrm{M}=25.02, \mathrm{SD}=4.535)$.

\section{RESULTS}

\subsection{Descriptive statistics}

The temperament to which the respondent belongs was obtained by collecting the $\mathrm{T}$ (correct) answers of the respondent on all items related to one type. Then the number of correct answers was divided by the total number of items of that temperament, and then the values obtained in that way on all the temperaments were compared to each other. Belongingness to one of the temperaments was determined on the basis of the highest numerical value. The range of all values ranged from 0 to 1 . All of the respondents who had the same score on two or more temperaments were classified as belonging to the category of mixed temperament. Most of the respondents characterized themselves as hyperthymic, the smallest number characterized themselves as depressive, while a certain number of respondents were classified as mixed. The structure of the sample in relation to the dominant temperament can be seen in Table 1.

Respondents also answered an additional question in which they were asked to express a global subjective impression of their own temperament by choosing one of the statements. The results in Table 2 show that the largest number of respondents consider 
themselves persons of a balanced temperament, while the smallest number of them consider themselves almost always sad.

Table 1 Number of respondents of a certain affective temperament

\begin{tabular}{lcc}
\hline Temperament & Number of participants & Percentage \\
\hline Depressive & 4 & $2.0 \%$ \\
Cyclothymic & 27 & $13.5 \%$ \\
Hyperthymic & 85 & $42.5 \%$ \\
Irritable & 9 & $4.5 \%$ \\
Anxious-cognitive & 35 & $17.5 \%$ \\
Anxious-somatic & 22 & $11.0 \%$ \\
Mixed & 18 & $9.0 \%$ \\
\hline
\end{tabular}

Table 2 Global impression of temperament

\begin{tabular}{lcr}
\hline Which of the following statements best describes your personality? & $\begin{array}{c}\text { Number of } \\
\text { participants }\end{array}$ & Percentage \\
\hline I'm almost always sad. & 7 & $3.5 \%$ \\
I am a completely cheerful person full of energy. & 27 & $13.5 \%$ \\
I have a lot of emotional ups and downs. & 45 & $22.5 \%$ \\
I get annoyed easily and the little things can throw me off balance. & 36 & $18.0 \%$ \\
I'm almost always worried. & 16 & $8.0 \%$ \\
I am a person with a balanced temperament. & 69 & $34.5 \%$ \\
\hline
\end{tabular}

The relationship between temperaments and the answer of the question about global impressions was examined using the Chi-square test of independence. The results are shown in Table 3. It can be concluded that there is a significant correlation between temperament

Table 3 Relationship between affective temperament and global subjective impression

\begin{tabular}{|c|c|c|c|c|c|c|c|c|}
\hline $\begin{array}{l}\text { Subjective } \\
\text { experience of } \\
\text { personality } \downarrow \\
\end{array}$ & $\begin{array}{l}\text { Temperament } \\
\qquad \rightarrow\end{array}$ & Depressive & Cyclothymic & Hyperthymic & Irritable & $\begin{array}{l}\text { Anxious- } \\
\text { cognitive }\end{array}$ & $\begin{array}{l}\text { Anxious- } \\
\text { somatic }\end{array}$ & Mixed \\
\hline $\begin{array}{l}\text { I'm almost } \\
\text { always sad. }\end{array}$ & $\begin{array}{c}\text { Participants No. } \\
\%\end{array}$ & $\begin{array}{c}1 \\
14.3 \% \\
\end{array}$ & $\begin{array}{c}2 \\
28.6 \% \\
\end{array}$ & $\begin{array}{c}1 \\
14.3 \% \\
\end{array}$ & $\begin{array}{c}0 \\
0 \% \\
\end{array}$ & $\begin{array}{c}0 \\
0 \% \\
\end{array}$ & $\begin{array}{c}1 \\
14.3 \% \\
\end{array}$ & $\begin{array}{c}2 \\
28.6 \% \\
\end{array}$ \\
\hline $\begin{array}{l}\text { I am a } \\
\text { completely } \\
\text { cheerful person } \\
\text { full of energy. }\end{array}$ & $\begin{array}{c}\text { Participants No. } \\
\% \\
\end{array}$ & $0 \%$ & $3.7 \%$ & $55.6 \%$ & $0 \%$ & $11.1 \%$ & $18.5 \%$ & $11.1 \%$ \\
\hline $\begin{array}{l}\text { I have a lot of } \\
\text { emotional ups } \\
\text { and downs. }\end{array}$ & $\begin{array}{c}\text { Participants No. } \\
\%\end{array}$ & $\begin{array}{c}1 \\
2.2 \%\end{array}$ & $\begin{array}{c}10 \\
22.2 \%\end{array}$ & $\begin{array}{c}11 \\
24.4 \%\end{array}$ & $\begin{array}{c}1 \\
2.2 \%\end{array}$ & $\begin{array}{c}9 \\
20.0 \%\end{array}$ & $\begin{array}{c}6 \\
13.3 \%\end{array}$ & $\begin{array}{c}7 \\
15.6 \%\end{array}$ \\
\hline $\begin{array}{l}\text { I get annoyed } \\
\text { easily and little } \\
\text { things can } \\
\text { upset me. }\end{array}$ & $\begin{array}{c}\text { Participants No. } \\
\%\end{array}$ & $\begin{array}{c}0 \\
0 \%\end{array}$ & $\begin{array}{c}8 \\
22.2 \%\end{array}$ & $25.0 \%$ & $13.9 \%$ & $25.0 \%$ & $11.1 \%$ & $\begin{array}{c}1 \\
2.8 \%\end{array}$ \\
\hline $\begin{array}{l}\text { I'm almost } \\
\text { always } \\
\text { worried. } \\
\end{array}$ & $\begin{array}{c}\text { Participants No. } \\
\%\end{array}$ & $\begin{array}{c}1 \\
6.3 \%\end{array}$ & $\begin{array}{c}1 \\
6.3 \%\end{array}$ & $\begin{array}{c}3 \\
18.8 \%\end{array}$ & $\begin{array}{c}1 \\
6.3 \%\end{array}$ & $\begin{array}{c}8 \\
50.0 \%\end{array}$ & $\begin{array}{c}1 \\
6.3 \%\end{array}$ & $\begin{array}{c}1 \\
6.3 \%\end{array}$ \\
\hline $\begin{array}{l}\text { I am a person } \\
\text { with a balanced } \\
\text { temperament. }\end{array}$ & $\begin{array}{c}\text { Participants No. } \\
\%\end{array}$ & $\begin{array}{c}1 \\
1.4 \%\end{array}$ & $\begin{array}{c}5 \\
7.2 \%\end{array}$ & $\begin{array}{c}46 \\
66.7 \%\end{array}$ & $\begin{array}{c}2 \\
2.9 \%\end{array}$ & $\begin{array}{c}6 \\
8.7 \%\end{array}$ & $\begin{array}{c}5 \\
7.2 \%\end{array}$ & $\begin{array}{c}4 \\
5.8 \%\end{array}$ \\
\hline & & & \multicolumn{2}{|c|}{$\begin{array}{l}\chi^{2} \text { test }=74.54 \\
p=.000^{* *}\end{array}$} & \multicolumn{4}{|c|}{$\begin{array}{c}\text { Cramer's V }=.273 \\
p=.000^{* * *}\end{array}$} \\
\hline
\end{tabular}


type and global impression of personality $(\mathrm{p}<.01)$. The value of Kramer's V shows that the large effect size is obtained (Pallant 2009). The grouping of respondents is most prominent for the answer "I am a person with a balanced temperament". Out of a total of 69 respondents who gave this answer, two thirds belong to the hyperthymic temperament.

Descriptive statistics of the data and results of the test of normality of distribution of perceived social support dimensions can be seen in Table 4. It can be noted that the variables do not have a normal distribution.

Table 4 Descriptive statistics

\begin{tabular}{lccccccc}
\hline Variables & Min & Max & AS & SD & Sk & Ku & K-S \\
\hline Emotional/Informational & 1 & 5 & 4.04 & 0.95 & -1.053 & .364 & $.171^{* *}$ \\
Practical & 1 & 5 & 4.18 & 0.90 & -1.205 & .798 & $.181^{* *}$ \\
Affective & 1 & 5 & 3.96 & 1.16 & -1.019 & -.011 & $.185^{\text {** }}$ \\
Positive Social Interactions & 1 & 5 & 3.88 & 1.01 & -.801 & -.143 & $.181^{\text {** }}$ \\
Perceived social support (general score) & 1 & 5 & 4.03 & 0.85 & -.974 & .499 & $.132^{* *}$ \\
\hline
\end{tabular}
$\mathrm{p}<0.01 ; \mathrm{K}-\mathrm{S}=$ Kolmogorov- Smirnov test of normality of distribution

Considering the authors of a Serbian validation study (Jovanović \& Gavrilov Jerković 2015) pointed out that it is only possible to reliably interpret the total score on the MOSSSS scale, differences between temperaments in the degree of the perception of available social support will be tested on the whole scale only. The results of the Kruskal-Wallis test show a difference between affective temperaments in the degree of perception of social support, which is shown in Table 5.

Table 5 Difference in the degree of perception of social support (Kruskal-Wallis test)

\begin{tabular}{lccc}
\hline Temperament & Mean rank & Kruskal-Wallis test & $\mathrm{P}$ \\
\hline Depressive & 32.25 & & \\
Cyclothymic & 83.43 & & \\
Hyperthymic & 113.15 & & $.011^{*}$ \\
Irritable & 83.78 & 16.49 & \\
Anx-cog. & 108.24 & & \\
Anx-som. & 78.73 & & \\
Mixed & 101.44 & & \\
\hline
\end{tabular}

"p $<0.05 ;$ Anx-cog. = anxious-cognitive; Anx-som. = Anxious-somatic temperament

In order to establish which of the temperaments are statistically significantly different from one another in the degree of perception of available social support, all of the temperaments were compared to each other. Table 6 only shows pairs of temperaments with statistically significantly different results. It can be seen that the depressive temperament perceive support to a lesser extent than the cyclothymic, hyperthymic, anxiety-cognitive and mixed temperament. On the other hand, the hyperthymic temperament perceives social support to a greater extent than the cyclothymic and anxiety-somatic temperament. The values of Cohen's $d$ show that the difference in the results between the types of temperament is small, since its values range between 0.1 and 0.2 (Pallant 2009). 
Table 6 Comparison of different temperaments (Man-Whitney U test)

\begin{tabular}{|c|c|c|c|c|}
\hline Temperament & Mean rank & Man-Whitney U test & $\mathrm{p}$ & Cohen's d \\
\hline $\begin{array}{l}\text { Depressive } \\
\text { Cyclothymic }\end{array}$ & $\begin{array}{r}7.50 \\
17.26\end{array}$ & 20 & $.046^{*}$ & 0.14 \\
\hline $\begin{array}{l}\text { Depressive } \\
\text { Hyperthymic }\end{array}$ & $\begin{array}{l}12.25 \\
46.54\end{array}$ & 39 & $.006^{* *}$ & 0.18 \\
\hline $\begin{array}{l}\text { Depressive } \\
\text { Anxious-cognitive }\end{array}$ & $\begin{array}{r}8.13 \\
21.36 \\
\end{array}$ & 22.50 & $.024^{*}$ & 0.16 \\
\hline $\begin{array}{l}\text { Depressive } \\
\text { Mixed }\end{array}$ & $\begin{array}{r}5.63 \\
12.81\end{array}$ & 12.5 & $.045^{*}$ & 0.14 \\
\hline $\begin{array}{l}\text { Cyclothymic } \\
\text { Hyperthymic }\end{array}$ & $\begin{array}{l}43.59 \\
60.60\end{array}$ & 799 & $.018^{*}$ & 0.17 \\
\hline $\begin{array}{l}\text { Hyperthymic } \\
\text { Anxious-somatic }\end{array}$ & $\begin{array}{l}57.74 \\
39.57\end{array}$ & 617.5 & $.014^{*}$ & 0.17 \\
\hline
\end{tabular}

\section{DISCUSSION}

The prevalence of certain temperaments in the sample is such that most people have a hyperthymic temperament, followed by anxiety-cognitive, cyclothymic, anxiety-somatic, irritable and, finally, depressive. The respondents also answered an additional question related to the global impression they have about their temperament. The Chi-square test for independence showed the existence of a significant relationship between temperaments and the global subjective impression about temperament. The largest percentage of respondents consider themselves to have a balanced temperament, and of the total number of respondents who gave this answer, two thirds belong to the hyperthymic temperament. The result can be explained by the fact that the hyperthymic temperament is characterized by optimism and self-confidence (Dembińska-Krajewska \& Rybakowski 2014), but also grandiose self-perception (Walsch et al. 2013) and excessive self-confidence (Ratković 2017), which are traits that can lead to such an answer. An additional interpretation is that the respondents choose this answer because of its social desirability and aspiration to present themselves in the best possible light (Ristić-Ignjatović et al. 2014). The offered explanations are supported by the tendency of the hyperthymic temperament to choose another answer that clearly contains socially desirable traits, and, at the same time, contributes to a positive image of oneself. That answer reads: "I am a completely cheerful person, full of energy". Other temperaments do not show a clear tendency to choose a particular answer to an additional question. This is probably due to the very small number of respondents by categories of variables.

The results indicate that people with a depressive temperament perceive social support to a lesser extent than the cyclothymic, hyperthymic, anxiety-cognitive and mixed temperament, which can be explained in several ways. First of all, the opinion of depressed people is characterized by what is known as Beck's cognitive triad, which refers to a negative assessment of oneself, current events and expected future (Golubović 2014). Similar thinking tendencies are measured by using the TEMPS-A scale (Ristić-Ignjatović et al. 2014). These people, because of the prediction that the current difficulties will continue indefinitely and that their immediate environment will continue to make excessive demands on achieving life goals (Possel \& Thomas 2011), can easily ignore the available social 
support from loved ones. The result can be related to the concept of learned helplessness, which belongs to the behavioral theories of depression, and suggests that depressed people will not avoid unpleasant states and situations, although they are given the opportunity to do so (Marić 2005). One of the possibilities in overcoming unpleasant situations could be the help of close others, i.e. available social support. Thus, these people can possibly deny important information in a stressful situation (informational support) or ignore the readiness of a person to listen to them and show them love and attention (emotional and affective support). Given that the depressive temperament and clinical forms of depressive disorders have similar manifestations, the previous explanations could be applied not only to clinical forms of depression, but also to the depressive temperament itself. All of the above is in line with the findings of previous research that suggests that the depressive temperament is associated with experiencing depressive symptoms (Walsch et al. 2012), but also with bipolar affective disorder (Iasevoli et al. 2013). The result is also consistent with research that has shown that depressive temperament partially coincides with behavioral inhibition, which is a risk factor in the development of social anxiety (Biederman et al. 1990; according to Signoretta et al. 2005), that it is related to a low ability to relate to others and problems in interpersonal relationships (Rovai et al. 2013a). There is, also, an explanation that adverse temperament dimensions, which are characteristic of the depressive temperament, may predispose an individual to having negative social interactions with significant others, which could be attributable to a reduced level of perceived support from friends and family (Windle 1992). In turn, a reduced level of social support contributes to the maintenance of depressive tendencies.

On the other hand, the hyperthymic temperament perceives social support to a greater extent than the cyclothymic and anxiety-somatic temperaments. The hyperthymic temperament is turned towards other people and easily expresses his needs and feelings (Dembińska-Krajewska \& Rybakowski 2014). According to the afore mentioned, it can be expected that these people will easily communicate their own need of help to others from their immediate surroundings. Their eloquence and sociableness will result in a clear articulation of needs which will make it easier for others to provide better and more precise support, which will, in return, make people with hyperthymic temperament perceive it more easily. The aforementioned confirms the protective effect of the hyperthymic temperament, which has been highlighted in previous studies (Karam et al. 2010). All these findings confirm the results of previous research that temperament plays a significant role in experiencing stress, determining the way people cope with a stressful situation (Rzeszutek, Partyka, \& Gołąb 2015; Tomas \& Chess 1977).

The limitations of this research should be taken into consideration. The research was conducted on a convenience sample, which is a type of non-probability sampling method, so the results cannot be generalized to the target population (Milas 2009). Also, it does not examine the relationship between perceived social support and other socio-economic factors, such as: unemployment, retirement, belongingness to vulnerable and marginalized groups, i.e. groups that are in a state of increased need for social support. The foregoing is particularly relevant to the way NEET youth perceive social support. This category includes all young people who are not unemployed, not in school or vocational training, which prevents them from acquiring competencies and job skills. This category has the opposite characteristics compared to the sample of young people from this research, which mainly includes students. The next limitation concerns the hyperthymic, irritable and anxious-somatic temperament scales which did not meet a minimum level of reliability, 
which is .7 for Cronbach's alpha (Pallant 2009). Finally, the number of respondents per temperament is very small, like in the depressive (4 respondents) and irritable temperament (9 respondents), which further complicates the drawing of reliable conclusions about the degree to which different temperaments perceive social support.

\section{CONCLUSION}

This research has shown that people with a predominantly depressive temperament are more likely to neglect available social support. The findings can be explained by a negative assessment of oneself and future events (Golubović 2014), as well as a negative assessment of a close environment, which is perceived as excessively demanding (Possel \& Thomas 2011). At the same time, these individuals will not avoid unpleasant states and situations, although such a possibility exists (Marić 2005), because of their inhibited behavior (Biederman et al., 1990; according to Signoretta et al., 2005). On the other hand, people with predominantly hyperthymic characteristics are able to easily establish communication with others (Dembińska-Krajewska \& Rybakowski 2014), which leads to better use of available resources in situations when they need help and support. Nevertheless, the relationship of the concepts from this research should be further investigated on larger samples, which should have different sociodemographic characteristics.

Acknowledgement: This research was supported by a research grant of the Faculty of Philosophy in Niš within the framework of the "Applied psychology in a function of the quality of life of an individual in the community" project.

\section{REFERENCES}

Akiskal, Hagop S., and Kareen K. Akiskal. "In search of Aristotle: temperament, human nature, melancholia, creativity and eminence." Affect Disord. 100, 1-3 (2007): 1-6. DOI: 10.1016/j.jad.2007.04.013

Andrews, Bernice, and G. W. Brown. "Social support, onset of depression and personality". Social Psychiatry and Psychiatric Epidemiology 23, 2 (1988): 99-108. DOI: 10.1007/BF01788429

Biederman, Joseph, Jerrold F. Rosenbaum, Dina R. Hirshfeld, Stephen V. Faraone, Elizabeth A. Bolduc, Michelle Gersten, Susan R. Meminger, Jerome Kagan, Nancy Snidman, and J. Steven Reznick. "Psychiatric correlates of behavioral inhibition in young children of parents with and without psychiatric disorders". Archives of General Psychiatry 47, 1 (1990): 21-26. DOI: 10.1001/archpsyc.1990.01810130023004

Bolger, Niall, Adam Zuckerman, and Ronald C. Kessler. "Invisible support and adjustment to stress". Journal of Personality and Social Psychology 79, 6 (2000): 953. DOI: 10.1037/0022-3514.79.6.953

Brown, George W., Bernice Andrews, Tirril Harris, Zsuzsanna Adler, and L. Bridge. "Social support, selfesteem and depression". Psychological Medicine 16, 4 (1986): 813-831. DOI: 10.1017/S0033291700011831

Cohen, Sheldon, and Thomas A. Wills. "Stress, social support, and the buffering hypothesis". Psychological Bulletin 98, 2 (1985): 310. DOI: 10.1037/0033-2909.98.2.310

Deelstra, Janna T., Maria CW Peeters, Wilmar B. Schaufeli, Wolfgang Stroebe, Fred RH Zijlstra, and Lorenz P. van Doornen. "Receiving instrumental support at work: when help is not welcome". Journal of Applied Psychology 88, 2 (2003): 324. DOI: 10.1037/0021-9010.88.2.324

Dembińska-Krajewska, Daria, and Janusz Rybakowski. "The Temperament Evaluation of Memphis, Pisa and San Diego Autoquestionnaire (TEMPS-A)-an important tool to study affective temperaments". Psychiatr Pol 48, 2 (2014): 261-76. PMID: 25016764

Dickerson, Sally S., and Margaret E. Kemeny. "Acute stressors and cortisol responses: a theoretical integration and synthesis of laboratory research". Psychological Bulletin 130, 3 (2004): 355. DOI: 10.1037/00332909.130.3.355 
Finch, John F., and William G. Graziano. "Predicting depression from temperament, personality, and patterns of social relations". Journal of Personality 69, 1 (2001): 27-55. DOI: 10.1111/1467-6494.00135

Frisch, Johanna U., Jan A. Häusser, Rolf van Dick, and Andreas Mojzisch. "Making support work: The interplay between social support and social identity". Journal of Experimental Social Psychology 55 (2014): 154-161. DOI: 10.1016/j.jesp.2014.06.009

Goldsmith, H. Hill, Arnold H. Buss, Robert Plomin, Mary Klevjord Rothbart, Alexander Thomas, Stella Chess, Robert A. Hinde, and Robert B. McCall. "Roundtable: What is temperament? Four approaches". Child Development (1987): 505-529. DOI: 10.2307/1130527

Golubović, Goran. "Psihijatrija za praktičare". Niš: Unigraf (2014).

Henderson, S., and D. G. Byrne, and P. Duncan-Jones. Neurosis and the Social Environment. Sidney: Academic, 1981.

Iasevoli, Felice, Alessandro Valchera, Emanuela Di Giovambattista, Massimo Marconi, Maria Paola Rapagnani, Domenico De Berardis, Giovanni Martinotti et al. "Affective temperaments are associated with specific clusters of symptoms and psychopathology: A cross-sectional study on bipolar disorder inpatients in acute manic, mixed, or depressive relapse." Journal of Affective Disorders 151, 2 (2013): 540-550. DOI: 10.1016/j.jad.2013.06.041

Jovanović, Veljko, and Vesna Gavrilov Jerković. "Validacija srpskog prevoda skale socijalne podrške mos-sss". Primenjena psihologija 8, 3 (2015): 245-264. DOI: 10.19090/pp.2015.3.245-264

Karam, Elie G., Mariana M. Salamoun, Joumana S. Yeretzian, Zeina N. Mneimneh, Aimee N. Karam, John Fayyad, Elie Hantouche, Kareen Akiskal, and Hagop S. Akiskal. "The role of anxious and hyperthymic temperaments in mental disorders: A national epidemiologic study". World Psychiatry 9, 2 (2010): 103110. DOI: $10.1002 / \mathrm{j} .2051-5545.2010 . t b 00287 . x$

Katainen, Saara, Katri Räikkönen, and Liisa Keltikangas-Järvinen. "Adolescent temperament, perceived social support, and depressive tendencies as predictors of depressive tendencies in young adulthood". European Journal of Personality 13, 3 (1999): 183-207. DOI: 10.1002/(SICI)1099-0984(199905/06)13:3<183::AIDPER327>3.0.CO;2-Z

Kawamura, Yoshiya, Tsuyoshi Akiyama, Takafumi Shimada, Takanobu Minato, Tadashi Umekage, Yoshihiro Noda, Ko Ukawa et al. "Six-year stability of affective temperaments as measured by TEMPS-A". Psychopathology 43, 4 (2010): 240-247. DOI: 10.1159/000313522

Lakey, Brian, and Edward Orehek. "Relational regulation theory: a new approach to explain the link between perceived social support and mental health". Psychological Review 118, 3 (2011): 482. DOI: 10.1037/a0023477

Lazarus, Richard S. Psychological Stress and the Coping Process, 1966.

Lin, Nan, Walter M. Ensel, Ronald S. Simeone, and Wen Kuo. "Social support, stressful life events, and illness: A model and an empirical test". Journal of Health and Social Behavior (1979): 108-119. DOI: 10.2307/2136433

Marić, J. Klinička psihijatrija (Moždani organski psihosindrom - MOPS) (11 izmenjeno i dopunjeno izdanje). Beograd: Megraf, 2005.

Milas, G. Istraživačke metode u psihologiji i drugim istraživačkim znanostima. Zagreb: Naklada Slap, 2009.

Nurullah, Abu Sadat. "Received and provided social support: A review of current evidence and future directions". American Journal of Health Studies 27, 3 (2012): 173-188.

Oniszczenko, Włodzimierz, and Maria Ledzińska. "Sex, affective temperaments and information stress". International Journal of Occupational Medicine and Environmental Health 32, 5 (2019): 635-644. DOI: 10.13075/ijomeh. 1896.01392

Pallant, Julie. SPSS priručnik za preživljavanje. Beograd: Mikro knjiga, 2009.

Pössel, Patrick, and S. Denise Thomas. "Cognitive triad as mediator in the hopelessness model? A three-wave longitudinal study". Journal of Clinical Psychology 67, 3 (2011): 224-240. DOI: 10.1002/jclp.20751

Ratković, Dragana. Uticaj temperamenta na nastanak i razvoj zavisnosti od opijata (doktorska disertacija). Novi Sad, Univerzitet u Novom Sadu, 2017.

Ristić-Ignjatović, Dragana, Darko Hinić, Daniel Bessonov, Hagop S. Akiskal, Kareen K. Akiskal, and Branko Ristić. "Towards validation of the short TEMPS-A in non-clinical adult population in Serbia". Journal of Affective Disorders 164 (2014): 43-49. DOI: 10.1016/j.jad.2014.04.005

Rovai, Luca, Annalisa Leonardi, Silvia Bacciardi, Angelo Giovanni Icro Maremmani, Fabio Rugani, Liliana Dell'Osso, Kareen Akiskal, Hagop S. Akiskal, and Icro Maremmani. "Discriminant and convergent validity of TEMPS-A [P]. Correlation with Occupational Personality Questionnaire (OPQ32) during a stressful situation". Journal of Affective Disorders 146, 1 (2013): 142-145. DOI: 10.1016/j.jad.2012.06.036

Rovai, Luca, A. G. Maremmani, F. Rugani, Silvia Bacciardi, M. Pacini, and Liliana Dell'Osso. "Do Akiskal \& Mallya's affective temperaments belong to the domain of pathology or to that of normality." Eur Rev Med Pharmacol Sci 17, 15 (2013): 2065-2079.

Rzeszutek, Marcin, Małgorzata Partyka, and Andrzej Gołąb. "Temperament traits, social support, and secondary traumatic stress disorder symptoms in a sample of trauma therapists". Professional Psychology: Research and Practice 46, 4 (2015): 213. DOI: 10.1037/pro0000024 
Sarafino, Edward P., and Timothy W. Smith. Health Psychology: Biopsychosocial Interactions. John Wiley \& Sons, 2014.

Sarason, Irwin G., Henry M. Levine, Robert B. Basham, and Barbara R. Sarason. "Assessing social support: The social support questionnaire". Journal of Personality and Social Psychology 44, 1 (1983): 127. DOI: 10.1037/0022-3514.44.1.127

Signoretta, Salvatore, Icro Maremmani, Antonia Liguori, Giulio Perugi, and Hagop S. Akiskal. "Affective temperament traits measured by TEMPS-I and emotional-behavioral problems in clinically-well children, adolescents, and young adults". Journal of Affective Disorders 85, 1-2 (2005): 169-180. DOI: 10.1016/ S0165-0327(03)00100-9

Strelau, Jan, and Bogdan Zawadzki. "Trauma and temperament as predictors of intensity of posttraumatic stress disorder symptoms after disaster". European Psychologist 10, 2 (2005): 124-135. DOI: 10.1027/10169040.10.2.124

Tarlov, Alvin R., John E. Ware, Sheldon Greenfield, Eugene C. Nelson, Edward Perrin, and Michael Zubkoff. "The Medical Outcomes Study: An application of methods for monitoring the results of medical care". Jama 262, 7 (1989): 925-930. DOI: 10.1001/jama.1989.03430070073033

Thoits, Peggy A. "Stress and health: Major findings and policy implications". Journal of Health and Social Behavior 51, 1_suppl (2010): S41-S53. DOI: 10.1177/0022146510383499

Thomas, Alexander, and Stella Chess. Temperament and Development. Brunner/Mazel, 1977.

Vázquez, Gustavo H., Leonardo Tondo, Lorenzo Mazzarini, and Xenia Gonda. "Affective temperaments in general population: A review and combined analysis from national studies". Journal of Affective Disorders 139, 1 (2012): 18-22. DOI: 10.1016/j.jad.2011.06.032

Walsh, Molly A., Leslie H. Brown, Neus Barrantes-Vidal, and Thomas R. Kwapil. "The expression of affective temperaments in daily life". Journal of Affective Disorders 145, 2 (2013): 179-186. DOI: 10.1016/j.jad. 2012.07.026

Walsh, Molly A., Amethyst M. Royal, Neus Barrantes-Vidal, and Thomas R. Kwapil. "The Association of affective temperaments with impairment and psychopathology in a young adult sample". Journal of Affective Disorders 141, 2-3 (2012): 373-381. DOI: 10.1016/j.jad.2012.03.016

Windle, Michael. "Temperament and social support in adolescence: Interrelations with depressive symptoms and delinquent behaviors". Journal of Youth and Adolescence 21, 1 (1992): 1-21. DOI: 10.1007/BF01536980

Zvizdić, Sibela. "Socijalna podrška i posttraumatska prilagodba mlađih adolescenata koji su doživjeli traumatski gubitak oca”. Paper presented at $16^{\text {th }}$ Ramir Bujas' Days, Zagreb, Croatia, December 11-13, 2003.

Zvizdić Sibela, "Socijalna podrška i rezilijencija kod djece i adolescenata", May 2015. http://www.ffeizdavastvo.ba/Books/Socijalna_podrska_i_rezilijencija_kod_djece_i_adolescenata.pdf.

\section{ODNOS AFEKTIVNOG TEMPERAMENTA SA PERCIPIRANOM SOCIJALNOM PODRŠKOM}

Osnovni cilj ovog rada je da ispita da li se osobe sa različitim afektivnim temperamentom (depresivni, ciklotimni, hipertimni, iritabilni, anksiozno-kognitivni, anksiozno-somatski i mešoviti) razlikuju u sklonosti percipiranju socijalne podrške. Uzorak je prigodan, ujednačen po polu, a čini ga 200 osoba mlađih od 35 godina. U istraživanju su primenjeni instrumenti: srpska verzija skale TEMPS-A, koja meri afektivne temperamente i srpska verzija Skale socijalne podrške Studije medicinskih ishoda (MOS-SSS). Rezultati pokazuju da depresivni temperament percipira socijalnu podršku u manjoj meri dostupnom od ciklotimnog $(p<.05)$, hipertimnog $(p<.01)$, anksioznokognitivnog $(p<.05)$ i mešovitog $(p<.05)$. Sa druge strane, hipertimni temperament je percipira dostupnijom od ciklotimnog $(p<.05) i$ anksiozno-somatskog temperamenta $(p<.05)$. Osnovni zaključak ovog istraživanja je da hipertimni temperament, koga odlikuje najveći broj poželjnih osobina poput optimizma, društvenosti, samouverenosti i elokventnosti, svoje socijalno okruženje percipira u većoj meri podržavajućim u odnosu na ostale tipove, što je posledica njegovih osobina $i$ dobre komunikacije sopstvenih potreba.

Ključne reči: afektivni temperament, percipirana socijalna podrška, dimenzije socijalne podrške 